\title{
Short communication: Comparison of the newly developed DVE/OEB (2010) system and the National Research Council (2001) model in modeling metabolic characteristics of proteins in dairy cattle
}

\author{
I. H. Gamage* and Peiqiang $\mathrm{Yu}^{*} \dagger^{1}$ \\ *Department of Animal and Poultry Science, College of Agriculture and Bioresources, University of Saskatchewan, 51 Campus Drive, Saskatoon, \\ SK, Canada, S7N 5A8 \\ †Tianjin Agricultural University, 22 Jinjin Road, Xiqing District, Tianjin 300384, China
}

\section{ABSTRACT}

The truly absorbed protein in the small intestine/ degraded protein balance (DVE/OEB) 2010 system is a recently developed protein evaluation system for ruminants. The objective of this study was to compare the DVE/OEB 2010 system with the National Research Council (2001) model in determining the metabolic characteristics of proteins in dairy cattle. The metabolic characteristics of proteins in bioethanol feedstock and their co-products were compared in terms of (1) truly absorbed rumen synthesized microbial protein in the small intestine; (2) truly absorbed rumen undegraded feed protein in the small intestine; (3) endogenous protein in the digestive tract; (4) total truly absorbed protein in the small intestine; and (5) protein degraded balance. The DVE/OEB 2010 system predicted $30 \%$ more truly absorbed rumen synthesized microbial protein in the small intestine, $4 \%$ more truly absorbed rumen undegraded feed protein in the small intestine, $64 \%$ more endogenous protein, 9\% more total truly absorbed protein in the small intestine, but $27 \%$ less degraded protein balance.

Key words: modeling nutrient supply, bioethanol feedstock and co-products, metabolic characteristics of proteins

\section{Short Communication}

Nutrient models facilitate correct predictions and estimations in dairy cattle feeding programs. With a better understanding of the ruminant digestive system, the integration of values obtained from in vivo and in vitro studies into mechanistic models helps to optimize animal performance in relation to the changes in ration. When the sample volume is limiting or a large number of samples or treatments must be evaluated for poten-

Received August 31, 2012.

Accepted May 8, 2013.

${ }^{1}$ Corresponding author: peiqiang.yu@usask.ca tial nutrient supply or animal performance, it is advantageous for nutritionists to use mathematical models rather than expensive, labor-intensive, and time-consuming animal trials. In the modern, high-producing dairy cow production system, the prior estimation of truly absorbable protein in small intestine is vital for both individual feeds and the diet. Therefore, different protein evaluation systems have been developed, although only few have been successful (Tamminga et al., 1994, 2007; Van Duinkerken et al., 2011).

Recently, the truly absorbed protein in the small intestine/degraded protein balance (DVE/OEB $)_{2010}$ system (Tamminga et al., 2007; Van Duinkerken et al., 2011) was developed. This system differs from the previous system (DVE/OEB ${ }_{1994}$; Tamminga et al., 1994). The DVE/OEB 2010 system uses a new approach to estimate the truly absorbable protein supply to small intestine and degraded protein balance in the rumen. The true protein supply to small intestine is discussed in the NRC (2001) model in terms of metabolizable protein. The DVE/OEB 2010 system considers the balance between rumen $\mathrm{N}$ and energy supply in terms that determine the contribution of microbial protein supply to the small intestine. The energy supply is based on each fermentable $\mathrm{OM}$ fraction in the DVE/OEB 2010 system (Tamminga et al., 2007; Van Duinkerken et al., 2011) but total digestible nutrients in NRC (2001).

The objective of this study was to compare the DVE/OEB 2010 system with the NRC (2001) model in the determination of the metabolic characteristics of proteins in dairy cattle. The metabolic characteristics of proteins were compared in terms of (1) truly absorbed rumen synthesized microbial protein in the small intestine $\left(\mathbf{D M C P} \mathbf{C P E 1 0}^{\mathrm{DV}}\right.$ vs. $\left.\mathbf{A} \mathbf{M C \mathbf { C P } ^ { \mathbf { N R C } 0 1 }}\right) ;(2)$ truly absorbed rumen undegraded feed protein in the small intestine (DRUP ${ }^{\text {DVE10 }}$ vs. ARUP ${ }^{\text {NRC01}}$ ); (3) endogenous protein in the digestive tract (DMFP ${ }^{\text {DVE10 }}$ vs. AECP ${ }^{\text {NRC01 }}$ ); (4) total truly absorbed protein in the small intestine (DVE ${ }^{\text {DVE10 }}$ vs. $\left.\mathbf{M P}^{\mathrm{NRC01}}\right)$; and (5) protein degraded balance $\left(\mathbf{O E B}^{\mathrm{DVE10}}\right.$ vs. $\left.\mathbf{D P B}^{\mathrm{NRC01}}\right)$. 


\section{Feed Sources and Data Sources Used for Modeling Nutrient Supply Study and Comparison}

Feeds used for modeling nutrient supply study and comparison were different original feedstock sources and their co-products from bioethanol processing. The detailed sampling description was previously reported (Gamage et al., 2012).

The data sources used for modeling nutrient supply study and comparison were from Gamage et al. (2012):

(1) Chemical composition (DM, ash, CP, crude fat, starch, NDF and ADF, acid and neutral detergent insoluble crude protein, nitrogen-adjusted NDF, NPN, soluble CP, NSC, ethanol-soluble carbohydrate, and macro- and microminerals) were reported previously (Gamage et al. 2012);

(2) Energy values: truly digestible CP, fatty acid, $\mathrm{NDF}$, and nonfiber carbohydrates; total digestible nutrient $\left(\mathbf{T D N} \mathbf{N}_{1 \times}\right) ; \mathrm{NE}_{\mathrm{M}}, \mathrm{NE}_{\mathrm{G}}$, digestible energy, $\mathrm{ME}$, and $\mathrm{NE}_{\mathrm{L}}$ at a production level of intake (3 or 4 times maintenance intake);

(3) Protein and carbohydrate subfractions: an immediately available NPN (PA), true potentially degradable protein $(\mathrm{PB})$, and undegradable protein acid-detergent insoluble crude protein, (PC); fraction PB was further subdivided into 3 subfractions depending on inherent degradation rates in rumen: rapidly degradable fraction (PB1), intermediately degradable fraction (PB2), and slowly degradable fraction (PB3); rapidly degradable carbohydrate $(\mathbf{C H O})$ fraction A (CA), intermediately degradable $\mathrm{CHO}$ fraction $\mathrm{B} 1$ (CB1), slowly degradable $\mathrm{CHO}$ fraction B2 (CB2), completely unavailable cell walls (CC);

(4) Particle size distribution;

(5) In situ rumen degradation kinetics of DM, CP, $\mathrm{NDF}, \mathrm{CHO}$, and starch: Soluble fraction $(\mathbf{S})$, potentially degradable fraction $(\mathbf{D})$, undegradable fraction $(\mathbf{U})$, degradation rate of $\mathrm{D}$ fraction $\left(\mathbf{K}_{\mathbf{d}}\right)$;

(6) Hourly effective degradation ratio;

(7) Estimated intestinal digestibility of rumen undegraded protein (Gamage et al., 2012).

The above data were used for modeling nutrient supply by both DVE/OEB 2010 system and the NRC (2001) model.

\section{Principle of the DVE/OEB 2010 System in Determining Metabolic Characteristics of Proteins}

The DVE/OEB 2010 system (Tamminga et al., 2007; Van Duinkerken et al., 2011) is an updated version of the DVE/OEB ${ }_{1994}$ system. The model describes DVE (total truly absorbable protein value) and OEB values (degraded protein balance) for each feed. The DVE value is calculated as follows: $\mathrm{DVE}=\mathrm{DMCP}+\mathrm{DRUP}$ - DMFP, where DMCP is the microbial protein synthesized in the rumen and digested in the intestine, DRUP is the feed protein not degraded in the rumen but digested in small intestine, and DMFP is the endogenous protein losses associated with digestion.

The DVE/OEB 2010 system (Tamminga et al., 2007; Van Duinkerken et al., 2011) does not calculate a fixed amount of microbial protein synthesis from the fermentable OM (FOM) as in the previous model. The DVE/ $\mathrm{OEB}_{2010}$ system considers that the amount of ATP that can be extracted from the feed differs among the components of a feed. The fermentable fraction of each nutrient is calculated as follows: FCOMP $=$ COMP $\times$ $\left\{\mathrm{S} \times\left(\mathrm{K}_{\mathrm{dS}} / \mathrm{K}_{\mathrm{dS}}+\mathrm{K}_{\mathrm{pS}}\right)+(\mathrm{W}-\mathrm{S}) \times \mathrm{K}_{\mathrm{d}(\mathrm{W}-\mathrm{S})} / \mathrm{K}_{\mathrm{d}(\mathrm{W}-\mathrm{S})}\right.$ $\left.+\mathrm{K}_{\mathrm{p}(\mathrm{W}-\mathrm{S})}+\mathrm{D} \times \mathrm{K}_{\mathrm{dD}} /\left(\mathrm{K}_{\mathrm{dD}}+\mathrm{K}_{\mathrm{pD}}\right)\right\}$, where FCOMP $=$ the effectively rumen degradable component $(\mathrm{g} / \mathrm{kg}$ of $\mathrm{DM}), \mathrm{S}=$ soluble fraction, $\mathrm{W}=$ washable fraction, $\mathrm{D}$ = potential degradable fraction, $\mathrm{K}_{\mathrm{p}}=$ passage rate, and $\mathrm{COMP}=$ the amount of relevant nutrient component in the feedstuff.

The microbial protein synthesized based on available rumen FOM depends on the ATP yield of each component, yield of microbial DM (Pirt, 1965; Tamminga et al., 2007; Van Duinkerken et al., 2011), and different bacterial strains and growing conditions (Russell and Strobel, 2005). With the equation of Pirt (1965), the actual microbial growth yield can be calculated as follows: $1 / \mathrm{Y}=\mathrm{M} / \mathrm{GR}+1 / \mathrm{Y}_{\max }$, where $\mathrm{Y}=$ yield of microbial DM (in g per mole of ATP), M = maintenance requirement of the microbes (mole of ATP $\times \mathrm{h}^{-1}$ per $\mathrm{g}$ of microbial material), $\mathrm{GR}=$ fractional growth rate $\left(\mathrm{h}^{-1}\right)$, and $\mathrm{Y}_{\max }=$ maximum microbial growth yield without losses in maintenance (g per mole of ATP).

\section{Principle of NRC (2001) Model in Determining Metabolic Characteristics of Proteins}

According to the NRC (2001) model, MP is composed of 3 major contributory protein sources. Total MP can be calculated as follows: MP $(\mathrm{g} / \mathrm{kg} \mathrm{DM})=$ $\mathrm{AMCP}+\mathrm{ARUP}+\mathrm{AECP}$, where AMCP is the absorbable microbial protein, ARUP is the truly absorbable rumen undegraded feed protein, and AECP is the truly absorbable endogenous protein in the small intestine.

To estimate the truly absorbed protein in small intestine, the digestibility of contributory protein should be considered. The NRC (2001) assumes that the microbial CP (MCP) contributed by bacteria and protozoa contains $80 \%$ true protein with the other $20 \%$ from nucleic acids. It also assumes that the digestibility of 
true protein of $\mathrm{MCP}$ is $80 \%$. Thus, $\mathrm{AMCP}=\mathrm{MCP} \times$ $0.8 \times 0.8$.

The truly absorbable rumen undegraded feed protein in NRC is estimated as follows: ARUP $=\%$ dRUP $\times$ RUP, where $\%$ dRUP = intestinal digestibility of RUP estimated using 3-step in vitro procedure or mobile technique.

The NRC (2001) assumes that the yield of MCP from $\mathrm{kg}$ of TDN is $130 \mathrm{~g}$. Therefore, MCP is calculated as follows: $\mathrm{MCP}(\mathrm{g} / \mathrm{kg} \mathrm{DM})=0.130 \times \mathrm{TDN}$. If $\mathrm{RDP}$ is less than $1.18 \times \mathrm{MCP}(\mathrm{TDN}-$ predicted yield), the MCP is calculated as MCP $(\mathrm{g} / \mathrm{kg} \mathrm{DM})=0.85 \times \mathrm{RDP}(\mathrm{g} /$ $\mathrm{kg}$ DM), where NRC (2001) assumes that $85 \%$ of the RDP is converted to MCP. After the digestibility of RUP (\% dRUP) is determined, ARUP is calculated as follows: $\operatorname{ARUP}(\mathrm{g} / \mathrm{kg}$ of $\mathrm{DM})=\operatorname{RUP}(\mathrm{g} / \mathrm{kg}$ of $\mathrm{DM}) \times \mathrm{dRUP}(\%)$.

The degraded protein balance (DPB) can be calculated for NRC (2001) as described by Yu et al. (2003). It is the difference between microbial proteins synthesized from rumen degraded feed protein (RDP) and the potential energy from anaerobic fermentation in the rumen; thus, DPB (g/ $\mathrm{kg}$ of DM) $=\mathrm{RDP}(\mathrm{g} / \mathrm{kg}$ of $\mathrm{DM})$ $-1.18 \times \mathrm{MCP}(\mathrm{g} / \mathrm{kg}$ of $\mathrm{DM})$.

\section{Statistical Analysis}

Statistical analyses were performed using the Mixed procedure of SAS version 9.2 (SAS Institute, 2009). The model used for the analysis was $Y_{i j k}=\mu+B_{i}+R_{j}+$ $e_{i j k}$, where $Y_{i j k}$ is the dependent variable, $\mu$ is the overall mean, $B_{i}$ is the fixed effect of treatment $[i=1,2$, the feedstock of wheat vs. wheat distillers dried grains with solubles (wDDGS), i $=1$ to 5 as the wheat batches, or $\mathrm{i}=\mathrm{I}$ to $\mathrm{V}$ as wDDGS batches], $\mathrm{R}_{\mathrm{j}}$ is the experimental run as a random effect, and $\mathrm{e}_{\mathrm{ijk}}$ is the associated error.

The paired $t$-test procedure of SAS (SAS Institute, 2009) and Pearson correlation analysis were performed to establish the relationship between the DVE/OEB 2010 system and the NRC (2001) model. The normality test to check the analysis model assumptions was performed using Proc Univariate with plot and normal options. For all the statistical analyses, significance was declared at $P<0.05$. The Tukey method was used for multi-treatment comparison. Means with different superscript letter groups were obtained with "pdmix800 SAS macro" (Saxton, 1998).

\section{Metabolic Characteristics of Protein with the DVE/OEB 2010 System}

The predicted values with the DVE/OEB-2007 (Tamminga et al., 2007) and the DVE/OEB-2010 (Van Duinkerken et al., 2011) system are summarized in Table 1. In the DVE/OEB 2010 system, MCP synthesis is based on each fraction (S, W-S, and D) of each nutrient component fermented in the rumen. The predicted MCP based on FOM was higher in wheat (162 vs. $97 \mathrm{~g} / \mathrm{kg}$ of DM in the co-products), and MCP based on RDP was higher in the co-products (280 vs. $94 \mathrm{~g} /$ $\mathrm{kg}$ of $\mathrm{DM})$. The higher nonstructural polysaccharide content in wheat (starch) (634 vs. $18 \mathrm{~g} / \mathrm{kg}$ of DM in the co-products) must have provided the higher ATP yields (Russell and Strobel, 2005; Tamminga et al., 2007). Among the sources of wheat and batches of the co-products, significant differences $(P<0.05)$ were observed in MCP based on both FOM and RDP. As a result, the estimated MCP absorption in the small intestine varied among the sources of feedstock grain as well as among the co-products. The range among the sources of wheat in MCP based on FOM was $24 \mathrm{~g} / \mathrm{kg}$ of DM, whereas that among the co-products was $15 \mathrm{~g} / \mathrm{kg}$ of DM. The MCP based on RDP varied by $17 \mathrm{~g} / \mathrm{kg}$ of DM among the sources of wheat, whereas that among the co-products was $35 \mathrm{~g} / \mathrm{kg}$ of DM.

The predicted undegraded feed protein absorbed in small intestine was about 3 times higher in the coproducts than in the feedstock (101 vs. $39 \mathrm{~g} / \mathrm{kg}$ of DM in feedstock sources). Predicted DRUP values differed significantly $(P<0.05)$ among the sources of wheat and among the co-products. Among the feedstock, the variation was $18 \mathrm{~g} / \mathrm{kg}$ of $\mathrm{DM}$; among the co-products, the predicted DRUP values varied by $28 \mathrm{~g} / \mathrm{kg}$ of DM. The predicted undegraded dry matter and the endogenous losses due to digestion were not significantly different between the feedstock and co-products, or among the sources of feedstock and the co-products.

The predicted total truly absorbed protein in small intestine (DVE) was significantly different $(P<0.05)$ among the co-products, with a range of $25 \mathrm{~g} / \mathrm{kg}$ of DM. The co-products were greater in both DVE and degraded protein balance (OEB) values (150 vs. $128 \mathrm{~g} / \mathrm{kg}$ DM in feedstock for DVE and 183 vs. $-68 \mathrm{~g} / \mathrm{kg}$ of DM in feedstock for OEB). The negative OEB values in the feedstock indicate, when modeling nutrient availability of feedstock as a single feed ingredient, the possibility of insufficient $\mathrm{N}$ supply to microbial production. However, when we formulate the diet, we need to consider all feedstuff OEB values. The total OEB value in a diet should be zero. Because the co-products contain higher values of DVE, these co-products could be a good true protein source in replacing expensive protein meal in animal diets if amino acid profiles do not differ much.

\section{Metabolic Characteristics of Protein with the NRC (2001) Model}

The effect of sources of original feedstock and their co-products on protein metabolic characteristics mod- 
eled with NRC (2001) is shown in Table 2. The NRC (2001) model assumes that MCP yield is $130 \mathrm{~g} / \mathrm{kg}$ of TDN (discounted) intake ( $3 \times$ maintenance intake). With the obtained results, RDP from wheat was less than requirement $(1.18 \times \mathrm{MCP})$, whereas $\mathrm{RDP}$ from the co-products exceeded the requirement. Therefore, MCP yield was predicted accordingly with $\mathrm{MCP}_{\mathrm{TDN}}$ and $\mathrm{MCP}_{\mathrm{RDP}}$. The MCP based on RDP was higher in wDDGS than that in the original feedstock and the values were 244 and $81 \mathrm{~g} / \mathrm{kg}$ of DM, respectively. The range among the sources of wheat for MCP based on RDP was $14 \mathrm{~g} / \mathrm{kg}$ of $\mathrm{DM}$, whereas that among the batches of the co-products was $32 \mathrm{~g} / \mathrm{kg}$ of DM. Based on TDN, MCP synthesis was higher in wheat compared with the co-products and the values were 104 and 96 $\mathrm{g} / \mathrm{kg}$ of DM in feedstock sources and their co-products, respectively. The MCP and AMCP were higher in the co-products compared with feedstock; the obtained values were 244 and $81 \mathrm{~g} / \mathrm{kg}$ of DM for co-products and 61 and $52 \mathrm{~g} / \mathrm{kg}$ of DM for feedstocks, respectively. Among the sources of original feedstock, we found a significant difference $(P<0.05)$ in AMCP, with a range of $9 \mathrm{~g} / \mathrm{kg}$ $\mathrm{DM}$; among the batches of co-products, the range was $3 \mathrm{~g} / \mathrm{kg}$ of DM.

The co-product was about 3 times higher in RUP compared with its parent feedstock (143 vs. $47 \mathrm{~g} / \mathrm{kg}$ of DM for co-product and feedstock, respectively). Feedstock source \#5 was highest in RUP $(59 \mathrm{~g} / \mathrm{kg}$ of DM) compared with the lowest, in source \#3 (34 g/ $\mathrm{kg}$ of $\mathrm{DM})$. The variation in RUP among batches of co-products was $25 \mathrm{~g} / \mathrm{kg}$ of DM. The same trend among the batches of co-products was observed with ARUP (26 $\mathrm{g} / \mathrm{kg}$ of DM). The higher ARUP value in co-products compared with feedstock makes co-products higher in MP value.

Because of the higher contribution of MCP and RUP from the co-products compared with feedstock, the coproduct was higher in total MP (161 vs. $91 \mathrm{~g} / \mathrm{kg}$ of DM for co-product and feedstock, respectively). Among the source of feedstock, the range of MP was $24 \mathrm{~g} / \mathrm{kg}$ of $\mathrm{DM}$; among the batches of co-products, the range was $32 \mathrm{~g} / \mathrm{kg}$ of DM.

The DPB was negative for all feedstock sources and positive for all co-products. The negative DPB value for feedstock indicates the potential shortage of $\mathrm{N}$ for microbial protein synthesis. The positive DPB indicates the potential $\mathrm{N}$ loss from the rumen. The average $\mathrm{DPB}$ of feedstock was $-28 \mathrm{~g} / \mathrm{kg}$ of DM, whereas that of coproducts was $175 \mathrm{~g} / \mathrm{kg}$ of DM. Among the sources of feedstock and batches of co-products, DPB varied by 16 and $38 \mathrm{~g} / \mathrm{kg}$ of DM, respectively. Significant differences $(P<0.05)$ were found in DPB among the sources of feedstock and among the batches of co-products, which indicates differences in protein metabolism in the rumen. In this study, we used single feed ingredient to evaluate DPB in the rumen; however, in the actual situation, a ration contains more feed ingredients that would compensate and balance the feed protein degradation in the rumen and potential microbial synthesis. Zero or slightly positive DPB to ensure sufficient N supply for microbial protein synthesis is recommended in a ration (DPB in a ration $=\mathrm{DPB}$ in feedstuff $1+$ DPB in feedstuff $2+\ldots)$.

In contrast to the results obtained by Nuez-Ortín and $\mathrm{Yu}$ (2010), in which both wheat and wDDGS were higher in RDP than in $1.18 \times \mathrm{MCP}_{\mathrm{TDN}}$, only wDDGS was higher in RDP than the $1.18 \times \mathrm{MCP}_{\mathrm{TDN}}$ in this study. The negative OEB values of wheat indicate the potential shortage of $\mathrm{N}$ for microbial protein synthesis. The negative OEB values of wheat compared with wDDGS is because the microbial protein synthesized based on energy released during anaerobic fermentation process $\left(\mathrm{MCP}_{\mathrm{FOM}}\right)$ is lower than the $\mathrm{MCP}$ synthesized based on RDP for the wDDGS. The obtained results for $\mathrm{OEB}$ values in wheat were not in agreement with those obtained by Nuez-Ortín and Yu (2010), in which OEB for wheat was in positive value. The values obtained for DVE were in agreement with the values obtained by Nuez-Ortín and Yu (2010). The results show that the wDDGS contained higher truly absorbable proteins of DVE, which could be used to replace expensive protein meal in animal diet.

\section{Comparison of DVE/OEB ${ }_{2010}$ System with NRC (2001) Model}

Comparisons and correlation analysis between the DVE/OEB 2010 system and the NRC (2001) model in the determination of metabolic characteristics of proteins in original feedstock (wheat) and bioethanol processing co-products (wDDGS) are presented in Table 3 . The difference between the 2 models was significant for all predicted nutrient supplies $\left(\mathrm{DMCP}^{\mathrm{DVE10}}\right.$ vs. $\mathrm{AMCP}^{\mathrm{NRC} 01}$ : $\mathrm{DRUP}^{\mathrm{DVE} 10}$ vs. $\mathrm{ABCP}^{\mathrm{NRC01}}$; $\mathrm{DMFP}^{\mathrm{DVE} 10}$ vs. $\mathrm{AECP}^{\mathrm{NRC} 01} ; \mathrm{DVE}^{\mathrm{DVE} 10}$ vs. $\mathrm{MP}^{\mathrm{NRC} 01} ; \mathrm{OEB}^{\mathrm{DVE} 10}$ vs. $\left.\mathrm{DPB}^{\mathrm{NRC} 01}\right)$. The greatest difference was found in truly absorbed rumen synthesized microbial protein in the small intestine $(+26 \mathrm{~g} / \mathrm{kg}$ of DM; $P<0.01)$ followed by degraded protein balance $(-16 \mathrm{~g} / \mathrm{kg}$ of DM; $P<0.01)$. The results showed that the DVE/OEB 2010 system predicted $30 \%$ higher $(P<0.01)$ truly absorbed rumen synthesized microbial protein in the small intestine, $4 \%$ higher $(P<0.01)$ truly absorbed rumen undegraded feed protein in the small intestine, $64 \%$ higher $(P<$ $0.01)$ endogenous protein, $9 \%$ higher $(P<0.05)$ total truly absorbed protein in the small intestine, but $27 \%$ lower $(P<0.01)$ degraded protein balance. Correlation analysis between the DVE/OEB 2010 system and NRC 
Table 1. Metabolic characteristics of proteins in the original feedstock (wheat) and bioethanol processing co-products (wheat distillers dried grains with solubles) using the DVE/ $\mathrm{OEB}_{2010}$ system (Tamminga et al., 2007; Van Duinkerken et al., 2010)

(1)

Original feedstock

\begin{tabular}{lcccccc} 
Item $^{2}$ & $\begin{array}{c}\text { Feedstock } \\
(\mathrm{n}=6)\end{array}$ & $\begin{array}{c}\text { Co-products } \\
(\mathrm{n}=6)\end{array}$ & SEM & $P$-value & $(\mathrm{n}=2)$ & $(\mathrm{n}=1$ \\
\hline DMCP $^{\text {DVE10 }}$ & $103^{\mathrm{a}}$ & $62^{\mathrm{b}}$ & 2.2 & $<0.01$ & $103^{\mathrm{ab}}$ & 1 \\
DRUP $^{\text {DVE10 }}$ & $39^{\mathrm{b}}$ & $101^{\mathrm{a}}$ & 5.6 & $<0.01$ & $40.8^{\mathrm{a}}$ & \\
DMFP $^{\text {DVE10 }}$ & 11 & 13 & 1.1 & 0.10 & 12 & \\
DVE $^{\text {DVE10 }}$ & $128^{\mathrm{b}}$ & $150^{\mathrm{a}}$ & 4.3 & $<0.01$ & 132 & 12 \\
OEB $^{\text {DVE10 }}$ & $-68^{\mathrm{b}}$ & $183^{\mathrm{a}}$ & 4.8 & $<0.01$ & $-60^{\mathrm{a}}$ & -
\end{tabular}

${ }_{\mathrm{a}, \mathrm{b}}$ Means with different letters within a row for feedstock and thei

${ }^{1}$ Multi-treatment comparison Tukey method.

${ }^{2} \mathrm{DMCP}^{\mathrm{DVE10}}=$ truly absorbed rumen synthesized microbial protein in small intestine; DRUP ${ }^{\mathrm{DVE} 10}=$ truly absorbed rumen undegraded feed protein in small intestine; DMFP ${ }^{\text {DVE10 }}$

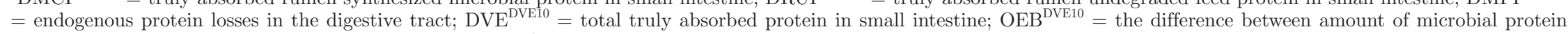
synthesized based on rumen-available energy and amount of microbial protein synthesized based on rumen-available $\mathrm{N}$.

Table 2. Metabolic characteristics of proteins in original feedstock (wheat) and bioethanol processing co-products (wheat distillers dried grains with solubles) using NRC (2001) model $^{1}$

\begin{tabular}{|c|c|c|c|c|c|c|c|c|c|c|c|c|c|c|}
\hline \multirow[b]{2}{*}{ Item $^{2}$} & \multirow[b]{2}{*}{$\begin{array}{l}\text { Feedstock } \\
\quad(\mathrm{n}=6)\end{array}$} & \multirow[b]{2}{*}{$\begin{array}{l}\text { Co-products } \\
\quad(\mathrm{n}=6)\end{array}$} & \multirow[b]{2}{*}{ SEM } & \multirow[b]{2}{*}{$P$-value } & \multicolumn{3}{|c|}{ Original feedstock } & \multirow[b]{2}{*}{ SEM } & \multirow[b]{2}{*}{$P$-value } & \multicolumn{3}{|c|}{ Bioethanol co-product } & \multirow[b]{2}{*}{ SEM } & \multirow[b]{2}{*}{$P$-value } \\
\hline & & & & & $\begin{array}{c}1 \\
(\mathrm{n}=2)\end{array}$ & $\begin{array}{c}3 \\
(\mathrm{n}=2)\end{array}$ & $\begin{array}{c}5 \\
(\mathrm{n}=2)\end{array}$ & & & $\begin{array}{c}\mathrm{I} \\
(\mathrm{n}=2)\end{array}$ & $\begin{array}{c}\text { III } \\
(\mathrm{n}=2)\end{array}$ & $\begin{array}{c}\mathrm{V} \\
(\mathrm{n}=2)\end{array}$ & & \\
\hline $\mathrm{AMCP}^{\mathrm{NRC} 01}$ & $52^{\mathrm{b}}$ & $61^{\mathrm{a}}$ & 1.0 & $<0.01$ & $56^{\mathrm{a}}$ & $52^{\mathrm{a}}$ & $47^{\mathrm{b}}$ & 1.6 & $<0.01$ & $62^{\mathrm{a}}$ & $62^{\mathrm{a}}$ & $59^{\mathrm{b}}$ & 0.1 & $<0.01$ \\
\hline ARUP $^{\mathrm{NRC} 01}$ & $35^{\mathrm{b}}$ & $96^{\mathrm{a}}$ & 4.1 & $<0.01$ & $40^{\mathrm{a}}$ & $20^{\mathrm{b}}$ & $45^{\mathrm{a}}$ & 4.2 & $<0.01$ & $98^{\mathrm{a}}$ & $109^{\mathrm{a}}$ & $80^{\mathrm{b}}$ & 7.1 & 0.01 \\
\hline $\mathrm{AECP}^{\mathrm{NRC} 01}$ & $4.2^{\mathrm{b}}$ & $4.4^{\mathrm{a}}$ & 0.01 & $<0.01$ & $4.2^{\mathrm{b}}$ & $4.2^{\mathrm{a}}$ & $4.2^{\mathrm{b}}$ & 0.00 & $<0.01$ & $4.4^{\mathrm{a}}$ & $4.3^{\mathrm{b}}$ & $4.3^{\mathrm{b}}$ & 0.01 & 0.03 \\
\hline $\mathrm{MP}^{\mathrm{NRC} 01}$ & $91^{\mathrm{b}}$ & $161^{\mathrm{a}}$ & 4.3 & $<0.01$ & $100^{\mathrm{a}}$ & $77^{\mathrm{b}}$ & $96^{\mathrm{a}}$ & 3.4 & $<0.01$ & $165^{\mathrm{a}}$ & $175^{\mathrm{a}}$ & $144^{\mathrm{b}}$ & 7.1 & $<0.01$ \\
\hline $\mathrm{DPB}^{\mathrm{NRC} 01}$ & $-28^{\mathrm{b}}$ & $175^{\mathrm{a}}$ & 4.5 & $<0.01$ & $-20^{\mathrm{a}}$ & $-29^{\mathrm{ab}}$ & $-35.7^{\mathrm{b}}$ & 2.9 & $<0.01$ & $186^{\mathrm{a}}$ & $150^{\mathrm{b}}$ & $188^{\mathrm{a}}$ & 6.6 & $<0.01$ \\
\hline
\end{tabular}

$\overline{\mathrm{a}, \mathrm{b}}$ Means with different letters within a row for feedstock and their co-products, for the sources of feedstock and for the batches of co-products, are significantly different $(P<0.05)$. ${ }^{1}$ Multi-treatment comparison by Tukey method.

${ }^{2} \mathrm{AMCP}^{\mathrm{NRC} 01}=$ truly absorbed microbial protein in small intestine; $\mathrm{ARUP}^{\mathrm{NR} 01}=$ truly absorbed feed protein in small intestine; $\mathrm{AECP}^{\mathrm{NRC} 01}=$ truly absorbed endogenous protein in the small intestine; $\mathrm{MP}^{\mathrm{NRC} 01}=$ truly absorbed total MP in small intestine; $\mathrm{DPB}^{\mathrm{NRC} 01}=$ degraded protein balance difference between potential microbial protein synthesis based on ruminally degraded feed protein and that based on energy - TDN available for microbial fermentation in the rumen. 
Table 3. Comparison and correlation analysis between the DVE/OEB 2010 system (DVE10; Tamminga et al., 2007; Van Duinkerken et al., 2010) and NRC (2001) model (NRC01) in the determination of metabolic characteristics of proteins in original feedstock (wheat) and bioethanol processing co-products (wheat distillers dried grains with solubles) ${ }^{1}$

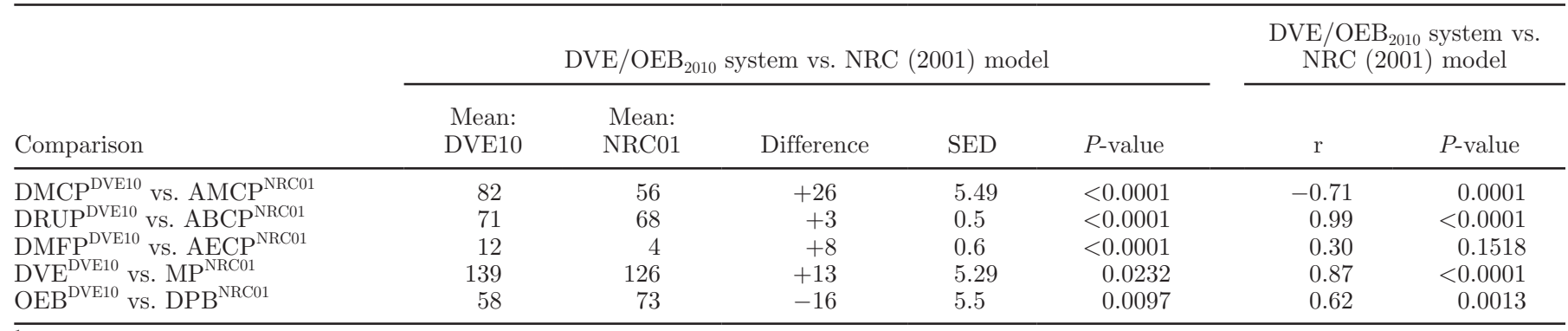

${ }^{1} \mathrm{SED}=$ standard error of the difference; $\mathrm{r}=$ Pearson correlation coefficient.

${ }^{2} \mathrm{DMCP}^{\mathrm{DVE10}} / \mathrm{AMCP}^{\mathrm{NRC} 01}=$ truly absorbed rumen synthesized microbial protein in small intestine $(\mathrm{g} / \mathrm{kg}$ of DM $) ; \mathrm{DRUP} \mathrm{DVE10}^{\mathrm{N}} / \mathrm{ABCP} \mathrm{NRC01}^{\mathrm{N}}=$ truly absorbed rumen undegraded feed protein in small intestine $\left(\mathrm{g} / \mathrm{kg}\right.$ of DM); DMFP ${ }^{\mathrm{DVE} 10} / \mathrm{AECP}^{\mathrm{NRC} 1}=$ endogenous protein losses in the digestive tract $(\mathrm{g} / \mathrm{kg}$ of $\mathrm{DM}) ; \mathrm{DVE}^{\mathrm{DVE} 10} / \mathrm{MP}^{\mathrm{NRC01}}=$ total truly absorbed protein in small intestine $(\mathrm{g} / \mathrm{kg}$ of $\mathrm{DM}) ; \mathrm{OEB}^{\mathrm{DVE10}} / \mathrm{DPB}^{\mathrm{NRC01}}=\mathrm{degraded}^{\mathrm{N}}$ protein balance $(\mathrm{g} / \mathrm{kg}$ of $\mathrm{DM})$.

(2001) model showed strong relationships for all predicted truly absorbed nutrients $(\mathrm{r}=0.62$ to $0.99 ; P<$ $0.01)$ except endogenous protein $(\mathrm{r}=0.30, P=0.15)$.

In conclusion, the DVE/OEB 2010 system predicted higher truly absorbed rumen synthesized microbial protein, higher truly absorbed rumen undegraded feed protein, higher endogenous protein, higher total truly absorbed protein in the small intestine, and lower degraded protein balance in comparison with the NRC (2001) model.

\section{ACKNOWLEDGMENTS}

Chair (PY) feed research programs have been supported by grants from Agricultural Bioproducts Innovation Program-Feed Opportunities from the Biofuels Industries (ABIP-FOBI) funding, Ministry of Agriculture Strategic Feed Research Chair Program, Beef Cattle Research Council (BCRC, Science Cluster, Calgary, AB, Canada), Natural Sciences and Engineering Research Council of Canada (NSERC, Ottawa, ON, Canada) grants, SaskCanola (Saskatoon,, SK, Canada), and the Saskatchewan Agricultural Development Fund (ADF). The authors thank A. Jonker and Z. Niu (University of Saskatchewan, Saskatoon, SK, Canada) for kind assistance and D. A. Christensen and G. Penner (University of Saskatchewan) for valuable discussion during the study.

\section{REFERENCES}

Gamage, I. H., A. Jonker, D. A. Christensen, and P. Yu. 2012. Metabolic characteristic of proteins and biomolecular spectroscopic pro- files in different feedstock (wheat) and their co-products (wheat distillers dried grains with solubles) from the same bioethanol processing plant. J. Dairy Sci. 95:6695-6715.

NRC. 2001. Nutrient Requirements of Dairy Cattle. 7th ed. National Academy Press, Washington, DC.

Nuez-Ortín, W. G., and P. Yu. 2010. Estimation of ruminal and intestinal digestion profiles, hourly degradation ratio and potential $\mathrm{N}$ to energy synchronization of co-products of bioethanol production. J. Sci. Food Agric. 90:2058-2067.

Pirt, S. J. 1965. The maintenance energy of bacteria in growing cultures. Proc. Roy. Soc. Lond. B Biol. 163:224-231.

Russell, J. B., and H. J. Strobel. 2005. Microbial energetics. Pages 229-261 in Quantitative Aspects of Ruminant Digestion and Metabolism. CABI Publishing, Wallingford, UK.

SAS Institute. 2009. SAS User's Guide: Statistics. Version 9.2. SAS Institute Inc., Cary, NC.

Saxton, A. M. 1998. A macro for converting mean separation output to letter groupings in PROC MIXED. Pages 1243-1246 in Proc. 23rd SAS User Group Int. SAS Institute Inc., Cary, NC.

Tamminga, S., G. G. Brandsma, J. Dijksta, G. V. Duinkerken, A. M. V. Vuuren, and M. C. Blok. 2007. Protein evaluation for ruminants: The DVE/OEB 2007 system. CVB documentation report nr. 53. CVB, Lelystad, the Netherlands.

Tamminga, S., W. M. Van Straalen, A. P. J. Subnel, R. G. M. Meijer, A. Steg, C. J. G. Wever, and M. C. Blok. 1994. The Dutch protein evaluation system: The DVE/OEB-system. Livest. Prod. Sci. 40:139-155.

Van Duinkerken, G., M. C. Blok, A. Bannink, J. W. Cone, J. Dijkstra, A. M. Van Vuuren, and S. Tamminga. 2011. Update of the Dutch protein evaluation system for ruminants: The DVE/OEB 2010 system. J. Agric. Sci. 149:351-367.

Yu, P., D. A. Christensen, and J. J. McKinnon. 2003. Comparison of the national research council-2001 model with the Dutch system (DVE/OEB) in the prediction of nutrient supply to dairy cows from forages. J. Dairy Sci. 86:2178-2192. 